\title{
Epidemiological study on leishmaniasis in an area of environmental tourism and ecotourism, State of Mato Grosso do Sul, 2006-2007
}

\author{
Estudo epidemiológico das leishmanioses em área de turismo ambiental e \\ ecoturismo, Estado de Mato Grosso do Sul, 2006-2007
}

\author{
Ana Rachel Oliveira de Andrade', Vânia Lúcia Brandão Nunes², \\ Eunice Aparecida Bianchi Galati ${ }^{3}$, Carla Cardozo Pinto de Arruda ${ }^{1}$, \\ Mirella Ferreira da Cunha Santos ${ }^{2}$, Maria Elizabeth Gizi Rocca ${ }^{4}$ \\ and Ricardo Braga Aquino ${ }^{4}$
}

\begin{abstract}
The aims of this study were to carry out a serological survey of canine leishmaniasis and identify the phlebotomine fauna in the urban area of Bonito, Mato Grosso do Sul. The serological survey was conducted on a sample of 303 dogs, by means of the indirect immunofluorescence test. Phlebotomines were captured using automated light traps. The serological survey found that $30 \%$ of the dogs were seropositive, both from the center and from all districts of the town. A total of 2,772 specimens of phlebotomines were caught and the species most found was Lutzomyia longipalpis (90.4\%), which corroborated its role as the vector of for canine visceral leishmaniasis in the region. Phlebotomines of the species Bichromomyia flaviscutellata (the main vector for Leishmania (Leishmania) amazonensis) and Nyssomyia whitmani (the vector for Leishmania (Viannia) brasiliensis) were also caught. The findings indicate the need for continuous epidemiological surveillance, with attention towards diminishing the vector breeding sites and the transmission of these diseases in that region.
\end{abstract}

Key-words: Leishmaniasis. Canine seroepidemiological survey. Phlebotomine fauna. Bonito. Bodoquena plateau.

\section{RESUMO}

0 presente trabalho teve por objetivo proceder ao levantamento sorológico para leishmanioses em cães e identificar a fauna flebotomínea da zona urbana de Bonito, Mato Grosso do Sul. 0 inquérito sorológico foi realizado em amostras de 303 cães com a utilização da reação de imunofluorescência indireta. As capturas de flebotomíneos realizaram-se com armadilhas automáticas luminosas. 0 inquérito sorológico identificou $30 \%$ cães reagentes procedentes do centro e de todos os bairros da cidade. Foram capturados 2,772 exemplares de flebotomineos, sendo a espécie mais frequiente foi Lutzomyia longipalpis (90.4\%), o que corrobora o seu papel de vetora de leishmaniose visceral canina na região. Foram capturados, também, flebotomíneos da espécie Bichromomyia flaviscutellata, principal vetora da Leishmania (Leishmania) amazonensis, e Nyssomyia whitmani, vetora da Leishmania (Viannia) braziliensis. Os achados indicam a necessidade de uma contínua vigilância epidemiológica, atentando para a diminuição dos criadouros dos vetores e da transmissão desses agravos naquela região.

Palavras-chaves: Leishmanioses. Inquérito soroepidemiológico canino. Fauna flebotomínea. Bonito. Planalto da Bodoquena.

\footnotetext{
1. Laboratory of Parasitology, Center of Biological and Health Sciences, University for the Development of the State and the Region of Pantanal, Campo Grande, MS, Brazil. 2. Laboratory of Parasitology, Center of Biological and Health Sciences, University for the Development of the State and the Region of Pantanal, Campo Grande, MS, Brazil. 3. Department of Epidemiology, Public Health Faculty, University of São Paulo, São Paulo, SP, Brazil. 4. Nucleus of Zoonoses Control of Bonito, Bonito, MS, Brazil. Financial support: CAPES and Manoel de Barros Foundation.

Address to: Dr. Ana Rachel Oliveira de Andrade. Rua Luiz Freire Benchetrit 258, Miguel Couto, 79040-140 Campo Grande, MS

Tel: 5567 3306-0916

e-mail: racheloliveira_83@hotmail.com

Received in 17/02/2009

Accepted in 29/09/2009
}

In humans, leishmaniases can occur in two clinical forms: American cutaneous leishmaniasis (ACL) and visceral leishmaniasis (VL) ${ }^{1520}$. ACL is among the six most important infectious and parasitic diseases in Brazil, occurring throughout the country ${ }^{22}$. VL is a potentially life-threatening disease for humans. In Brazil, its etiology is attributed to Leishmania (Leishmania) chagasi and the disease presents differentiated geographical, climatic and social characteristics according to its widespread distribution involving all five Brazilian geographical regions?. 
Among the pets that may host the etiological agent for VL, dogs are considered to be the most important in epidemiological terms. They serve as a source of food for the vector, and bring the vector into contact with humans. Their high population density and their susceptibility to Leishmania chagasi are factors that make dogs the main domestic reservoir for VL in the Americas ${ }^{20}$.

The natural vectors for protozoa of the genus Leishmania are dipterous, from the family Psychodidae, subfamily Phlebotominae. Except for some very rare autogenous species, female phlebotomines need blood from vertebrates to maintain their ovaries and mature their eggs, hence their importance in leishmaniasis transmission ${ }^{25}$.

Like in other Brazilian states, leishmaniasis presents widespread geographical distribution in Mato Grosso do Sul (MS). In 2006, 222 cases of VL and 143 cases of ACL were confirmed. In 2007 up to March, 37 cases of ACL and 77 of VL had already been reported in 17 municipalities, and Bonito was among them ${ }^{124}$. In spite of these data, investigations on the etiology and particular features of the transmission processes of these diseases are scarce in Mato Grosso do Sul ${ }^{416}$.

The above facts justified the present study, in which the aims were to carry out a serological survey on canine leishmaniasis and identify phlebotomines in the urban area of Bonito, with a view to obtaining support for planning policies to control epidemics in this region, which is an important tourist center in Brazil.

\section{MATERIAL AND METHODS}

Area of study. Bonito is located in the southwestern region of Mato Grosso do Sul, at $21^{\circ} 07^{\prime} 16^{\prime \prime} S$ and $56^{\circ} 28^{\prime} 55^{\prime \prime}$, in the geomorphological unit called the Bodoquena plateau. The area of the municipality area is $4,934 \mathrm{~km}^{2}$, and the population density is 3.6 inhabitants $/ \mathrm{km}^{2}{ }^{10}$

The region has a recognized infrastructure for ecotourism, i.e. activities developed to minimize the deleterious effects of frequent human action on nature. The municipality of Bonito is considered to be an important center for ecotourism both at national and at international level, and its main attractions are its natural landscape, rivers of crystal-clear water, waterfalls, grottos and caves.

Serological survey on canine leishmaniasis. The urban area of Bonito is divided into six zones: 1, 2, 3, 4, 5 and 6, totaling 364 street blocks. The number of blocks in each zone was surveyed, and then around 30\% of the blocks were randomly selected, which resulted in a total of 108 (Table 1).

With the help of the Bonito Zoonosis Control Center, a canine census was carried out in all houses in the selected blocks. The number of dogs and their size, type and color were recorded for later identification.

Next, five animals per block were again randomly selected and blood was collected from them by means of puncturing the cephalic vein using a 30x8mm needle. The material was left for clot retraction for a varying length of time and then centrifuged at $2,500 \mathrm{rpm}$, for five minutes, to obtain the serum. Next, the serum from each animal was divided into two portions and placed in Eppendorf tubes. After identification, these tubes were stored in a freezer for later serological assays.

To estimate the number of statistically valid samples and take into account animal refusals and losses, among other factors that could negatively interfere with the results, the number of $\mathrm{dog}$ samples (five) to be collected from each block was multiplied by the total number of blocks in the town, thus totaling 1,820 dogs. Taking a 95\% confidence interval, margin of error of $6 \%$ and estimated prevalence of $50 \%$, it was found that $n=233$ would be enough for the present study. Nonetheless, out of the 1,820 dogs, 303 were sampled because the natural prevalence of leishmaniasis in the region was unknown.

The indirect immunofluorescence antibody test was performed by using a kit for canine leishmaniasis supplied by Bio-Manguinhos, FIOCRUZ, Rio de Janeiro. Samples that showed fluorescent promastigotes, including the flagellum, were considered positive. Those that showed parasites without fluorescence and reddish coloration were considered nonpositive. Serum that was positive at a titer 1:40 was tested again in serial dilutions halving the concentration, i.e. 1:40, 1:80, 1:160, 1:320, 1:640 and 1:1,280, in order to determine the antibody titers in the samples. Those with titers greater than or equal to than 1:80 were considered positive.

Capture and identification of phlebotomines, and analysis performed. Phlebotomines were captured fortnightly using CDC automatic light traps ${ }^{14}$ between March 2006 and February 2007 , from $6 \mathrm{pm}$ to $6 \mathrm{am}$, irrespective of daylight saving time. The capture sites comprised 12 environments and 16 ecotopes, covering both the center and the different districts of Bonito.

In order to identify the phlebotomines, the structures of the head, chest and abdomen at a specific level were used; the male and female genitalia were enhanced 5 .

\section{TABLE 1}

Blocks selected in the urban zones of Bonito, Mato Grosso do Sul, Brazil

\begin{tabular}{ll}
\hline Zones & Selected Blocks $(30 \%)$ \\
\hline Zone 1 (95 blocks) & $02,03,10,11,13,15,19,20,23,27,30,37,44,50,53,54,55,60,61,66,67,74,75,80,83,86,90,95(28$ blocks $)$ \\
Zone 2 (67 blocks) & $04,12,30,15,19,20,38,23,26,28,32,37,45,49,50,54,63,64,66,11(20$ blocks $)$ \\
Zone 3 (58 blocks) & $03,05,08,09,22,18,25,31,32,38,47,39,30,45,44,42,35(17$ blocks $)$ \\
Zone 4 (44 blocks) & $04,05,10,15,16,14,22,29,33,35,38,42,28(13$ blocks $)$ \\
Zone 5 (87 blocks) & $02,04,05,08,14,17,23,28,31,34,38,42,46,47,49,50,54,55,59,64,70,75,78,82,84,85(26$ blocks $)$ \\
Zone 6 (13 blocks) & $02,04,05,09$ (4 blocks $)$ \\
\hline
\end{tabular}


To determine the abundance of a certain species in relation to others, at a given time and location, the Roberts and Hsi standard abundance index (SAI) was used ${ }^{21}$. The Williams Geometric Average $^{9}$ was used to quantify the frequency and regularity of the most abundant species. The Shannon Index (H) was used to calculate the relationship between the number of species and the number of individuals captured in a determined ecotope and Pielou's Index $(\mathrm{J})$ was used to measure the proportion of the contribution of each species in the community of a given ecotope $^{8}$. The relative frequency of the species was measured by the percentage method.

\section{RESULTS}

Dogs. Out of the 303 dogs, 91 (30\%) were seropositive according to the immunofluorescence test, with titers greater than or equal to $1: 80$, while $202(70 \%)$ were non-positive. The seropositive dogs were both from the center and from all the districts (Table 2).
Phlebotomines. According to the classification proposed by Galati ${ }^{5}$, the phlebotomines captured belonged to four subtribes, seven genera and 13 species: Brumptomyiina: Brumptomyia avellari, Brumptomyia brumpti; Psychodopygina: Bichromomyia flaviscutellata, Nyssomyia whitmani, Psathyromyia (Psathyromyia) shannoni, Psathyromyia (Forattiniella) aragao $i$, Psathyromyia punctigeniculata, Psathyromyia campograndensis; Sergentomyiina: Micropygomyia quinquefer; Lutzomyiina: Evandromyia corumbaensis, Evandromyia (Aldamyia) lenti, Lutzomyia longipalpis.

Table 3 and Table 4 show the number of phlebotomines captured fortnightly, between March 2006 and February 2007. Lutzomyia longipalpis was present in all of the 12 environments within which captures were made, thus demonstrating the widespread distribution of this species within the urban area of Bonito. This species was mostly found in areas surrounding homes, near animal shelters (Table 3 and Table 4 ). The species that was second most frequently found was Micropigomyia quinquefer, especially indoors. This is the species most often found in the savanna. Evandromyia sallesi came third in frequency and was

TABLE 2

Numbers of positive and non-positive canine samples collected between March 2006 and February 2007 in Bonito, Mato Grosso do Sul, Brazil.

\begin{tabular}{|c|c|c|c|c|c|}
\hline Zones of Bonito & Number of samples & Positive samples & Non-positive samples & $\%$ positive & $\%$ non-positive \\
\hline Zone 1 & 71 & 15 & 56 & 21.1 & 78.9 \\
\hline Zone 2 & 57 & 22 & 35 & 38.6 & 61.4 \\
\hline Zone 3 & 75 & 18 & 57 & 24.0 & 76.0 \\
\hline Zone 4 & 39 & 2 & 37 & 5.1 & 94.9 \\
\hline Zone 5 & 48 & 31 & 17 & 64.6 & 35.4 \\
\hline Zone 6 & 13 & 3 & 10 & 23.1 & 76.9 \\
\hline Total & 303 & 91 & 212 & 30.0 & 70.0 \\
\hline
\end{tabular}

TABLE 3

Phlebotomines captured fortnightly with CDC light traps, according to species, sex, ecotopes, index of species diversity by Shannon (H) and index of species equitability by Pielou (J), in 12 environments of Bonito, MS, Brazil, from March 2006 through February, 2007.

\begin{tabular}{|c|c|c|c|c|c|c|c|c|c|c|c|c|c|c|c|c|c|c|c|c|}
\hline \multirow[b]{3}{*}{ Species } & \multirow{2}{*}{\multicolumn{2}{|c|}{$\begin{array}{c}\text { Property } 1 \\
\text { yard }\end{array}$}} & \multirow{2}{*}{\multicolumn{2}{|c|}{$\begin{array}{l}\text { House } 1 \\
\text { hencoop }\end{array}$}} & \multicolumn{4}{|c|}{ Smallholding 1} & \multicolumn{4}{|c|}{ Hillside savanna } & \multicolumn{4}{|c|}{ Forest } & \multicolumn{4}{|c|}{ Smallholding 2} \\
\hline & & & & & \multicolumn{2}{|c|}{ pigpen } & \multicolumn{2}{|c|}{ veranda } & \multicolumn{2}{|c|}{ slope } & \multicolumn{2}{|c|}{ base } & \multicolumn{2}{|c|}{ edge } & \multicolumn{2}{|c|}{ interior } & \multicolumn{2}{|c|}{ veranda } & \multicolumn{2}{|c|}{ yard } \\
\hline & M & $\mathrm{F}$ & M & $\bar{F}$ & M & $\mathrm{F}$ & $\mathrm{M}$ & $\mathrm{F}$ & M & $\bar{F}$ & $\mathrm{M}$ & $\mathrm{F}$ & M & $\bar{F}$ & M & $\bar{F}$ & M & $\bar{F}$ & M & $\mathrm{F}$ \\
\hline Bicromomyia flaviscutellata & - & - & - & - & - & - & - & - & - & - & - & - & 9 & 6 & - & 5 & 1 & 4 & - & 9 \\
\hline Brumptomyia avellari & - & - & - & - & - & 1 & - & - & - & - & - & - & 6 & - & 3 & 4 & - & - & - & 1 \\
\hline Brumptomyia brumpti & - & - & - & 1 & - & 1 & - & - & - & - & - & 2 & 9 & 4 & 6 & 12 & 2 & 2 & - & 1 \\
\hline Evandromyia corumbaensis & - & - & - & - & - & - & - & - & - & - & 3 & 1 & - & - & - & - & 2 & 2 & 1 & - \\
\hline Evandromyia. lenti & - & - & - & - & - & - & - & - & - & - & - & 1 & - & - & - & - & - & - & - & - \\
\hline Evandromyia sallesi & - & - & 1 & 9 & - & 4 & 1 & - & - & 3 & 1 & 4 & - & 1 & - & - & 2 & 9 & 1 & 8 \\
\hline Lutzomyia longipalpis & 107 & 9 & 773 & 115 & 254 & 55 & 13 & 4 & 24 & 7 & 22 & 14 & - & 1 & - & 2 & 248 & 58 & 556 & 68 \\
\hline Micropigomyia quinquefer & - & - & - & - & - & - & - & - & 1 & 9 & 25 & 38 & - & 1 & - & - & - & - & - & 1 \\
\hline Nyssomyia whitmani & - & - & 2 & 1 & 1 & 1 & - & - & 1 & - & - & - & 2 & 2 & 1 & 1 & 2 & 1 & - & 1 \\
\hline Psathyromyia aragao $i$ & - & - & - & - & - & - & - & - & - & - & - & - & 1 & - & 2 & - & - & - & - & - \\
\hline Psathyromyia campograndensis & - & - & - & 1 & - & - & - & - & - & - & - & - & - & - & - & - & - & - & - & - \\
\hline Psathyromyia punctigeniculata & - & - & - & - & - & - & - & - & - & - & - & - & - & - & - & - & - & - & - & 1 \\
\hline Psathyromyia shannoni & - & - & 2 & - & - & - & - & - & - & - & 1 & 1 & 2 & - & 1 & - & 2 & - & 2 & - \\
\hline Total & 107 & 9 & 778 & 127 & 255 & 62 & 14 & 4 & 26 & 19 & 52 & 61 & 29 & 15 & 13 & 24 & 259 & 76 & 560 & 90 \\
\hline Shannon $(\mathrm{H})$ & \multicolumn{2}{|c|}{0} & \multicolumn{2}{|c|}{0,11} & \multicolumn{2}{|c|}{0,14} & \multicolumn{2}{|c|}{0,21} & \multicolumn{2}{|c|}{0,85} & \multicolumn{2}{|c|}{1,12} & \multicolumn{2}{|c|}{1,70} & \multicolumn{2}{|c|}{1,50} & \multicolumn{2}{|c|}{0,43} & \multicolumn{2}{|c|}{1,0} \\
\hline Pielou (J) & \multicolumn{2}{|c|}{0} & \multicolumn{2}{|c|}{0,06} & \multicolumn{2}{|c|}{0,08} & \multicolumn{2}{|c|}{0,30} & & & & & & & & & 0 , & & & 43 \\
\hline
\end{tabular}

M: male, F: female. 
TABLE 4

Phlebotomines captured fortnightly with CDC light traps, according to species, sex, ecotopes, index of species diversity by Shannon (H) and index of species equitability by Pielou (J), in 12 environments of Bonito, MS, Brazil, from March 2006 through February, 2007.

\begin{tabular}{|c|c|c|c|c|c|c|c|c|c|c|c|c|c|c|c|c|}
\hline \multirow[b]{2}{*}{ Species } & \multicolumn{2}{|c|}{$\begin{array}{l}\text { House } 2 \\
\text { hencoop }\end{array}$} & \multicolumn{2}{|c|}{$\begin{array}{l}\text { House } 3 \\
\text { hencoop }\end{array}$} & \multicolumn{2}{|c|}{$\begin{array}{c}\text { House } 4 \\
\text { yard }\end{array}$} & \multicolumn{2}{|c|}{$\begin{array}{c}\text { Animal } \\
\text { outhouse }\end{array}$} & \multicolumn{2}{|c|}{$\begin{array}{c}\text { House } 5 \\
\text { yard }\end{array}$} & \multicolumn{2}{|c|}{$\begin{array}{c}\text { Property } 2 \\
\text { kennel }\end{array}$} & \multicolumn{2}{|c|}{ Total } & \multicolumn{2}{|c|}{ Total } \\
\hline & M & $\mathrm{F}$ & M & $\mathrm{F}$ & M & $\mathrm{F}$ & M & $\mathrm{F}$ & M & $\mathrm{F}$ & M & $\mathrm{F}$ & M & $\mathrm{F}$ & MF & $\%$ \\
\hline Bicromomyia flaviscutellata & - & - & - & - & - & - & - & - & - & - & 1 & - & 11 & 24 & 35 & 1.26 \\
\hline Brumptomyia avellari & - & - & - & - & - & - & - & - & - & - & - & - & 9 & 6 & 15 & 0.54 \\
\hline Brumptomyia brumpti & - & 1 & - & - & - & - & - & - & - & - & - & - & 17 & 24 & 41 & 1.47 \\
\hline Evandromyia corumbaensis & - & - & 1 & 1 & - & - & 1 & - & - & - & - & - & 8 & 4 & 12 & 0.43 \\
\hline Evandromyia lent $i$ & - & - & - & - & - & - & - & - & - & - & - & - & - & 1 & 1 & 0.03 \\
\hline Evandromyia salles $i$ & - & 1 & 1 & 3 & 3 & 1 & 1 & - & - & - & - & 1 & 11 & 44 & 55 & 1.98 \\
\hline Lutzomyia longipalpis & 69 & 11 & 10 & 10 & 14 & 2 & 40 & 10 & 4 & - & 1 & - & 2,135 & 369 & 2,504 & 90.40 \\
\hline Micropigomyia quinquefer & - & - & - & - & - & - & - & - & - & - & - & 1 & 26 & 50 & 76 & 2.73 \\
\hline Nyssomyia whitmani & - & - & - & - & - & - & - & - & - & - & - & - & 9 & 7 & 16 & 0.57 \\
\hline Psathyromyia aragao $i$ & - & - & - & - & - & - & - & - & - & - & - & - & 3 & - & 3 & 0.10 \\
\hline Psathyromyia campograndensis & - & - & - & - & - & - & - & - & - & - & - & - & - & 1 & 1 & 0.03 \\
\hline Psathyromyia punctigeniculata & - & - & - & - & - & 1 & - & - & - & - & - & - & - & 2 & 2 & 0.07 \\
\hline Psathyromyia shannoni & - & - & - & - & - & - & - & - & - & - & - & - & 10 & 1 & 11 & 0.39 \\
\hline Total & 69 & 13 & 12 & 14 & 17 & 4 & 42 & 10 & 4 & 3 & 2 & 2 & 2,239 & 533 & 2,772 & 100.0 \\
\hline Shannon $(\mathrm{H})$ & 0,13 & & 0,68 & & 0,66 & & 0,18 & & 0 & & 0,05 & & & & $\%$ male & 80.77 \\
\hline Pielou (J) & 0,11 & & 0,61 & & 0,60 & & 0.16 & & 0 & & 0,03 & & & & $\%$ female & e 19.23 \\
\hline
\end{tabular}

M: male, F: female.

found in most of the environments studied, although in small numbers. Brumptomyia brumpti was present indoors and in areas surrounding homes, especially at the edges of and inside in wooded areas. Bicromomyia flaviscutellata came fifth and was mostly found in the woods, but some individuals were also found indoors.

The diversity index for phlebotomine species ranged from $\mathrm{H}=0$ to $H=1.70$. The highest values were found at the edges of wooded areas $(H=1.70)$, inside woods $(H=1.50)$, in a farmyard in zone $2(H=1.0)$ and in hillside savannah $(H=0.85)$. Thus, the greatest diversity was found in regions with rich vegetation, where nine out of the 13 species studied were found (Table 3 and Table 4).

In the areas surrounding homes, the index ranged from $\mathrm{H}=0$ to $\mathrm{H}=0.66$, and indoors, it ranged from $\mathrm{H}=0$ to $\mathrm{H}=$ 0.63 . The lowest indices occurred at House 5 in zone 1 , with $\mathrm{H}=$ 0, i.e. only one species occurred, namely Lutzomyia longipalpis. It was noteworthy that the diversity index was influenced not only by the number of species found in a given place, but also by the total number of individuals captured.

Regarding the proportion that each species contributed in the community of a given ecotope, Table 3 and Table 4 show that $\mathrm{J}=0$ at House 5 in zone 1, i.e. only one species was present. Both at the edges and inside the woods, the index was high $(\mathrm{J}=0.77)$, thus demonstrating that there were equal proportions among the species captured.

Table 4 shows the standard abundance index. The most abundant species was Lutzomyia longipalpis with $\mathrm{SAI}=0.90$. Thus, on this scale, with a value close to one, this finding indicated maximum abundance.

The correlation between the mean temperature and rainfall in the region over the period analyzed and the frequency and regularity of the most abundant species collected (Lutzomyia longipalpis) was investigated (Figure 1). This species was reported throughout the year, with the highest incidence in the

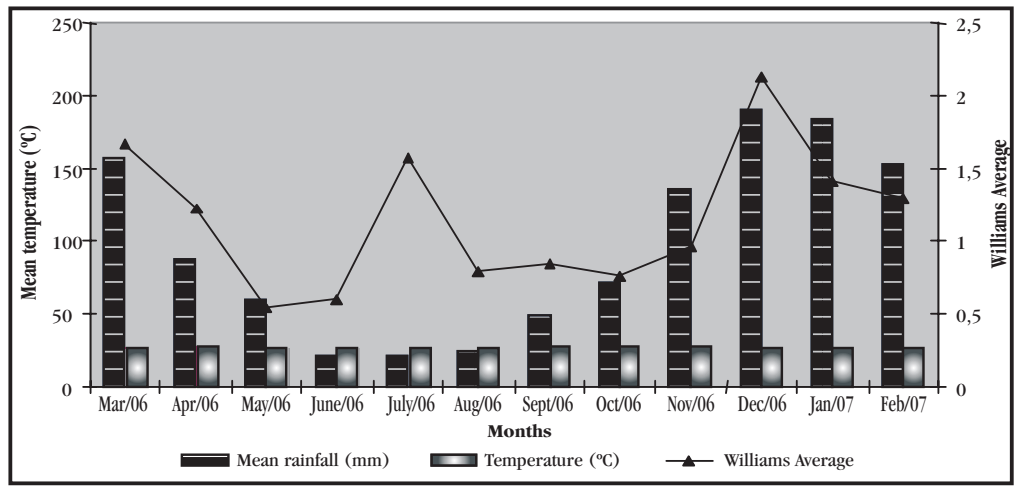

FIGURE 1

Mean monthly temperature $\left({ }^{\circ} \mathrm{C}\right)$, monthly rainfall $(\mathrm{mm})$ and monthly frequency (Williams Average) of Lutzomyia longipalpis captured in 16 ecotopes of Bonito, MS, Brazil, from March 2006 through February, 2007. 
rainiest months: March, November and December 2006 and January and February 2007. However, in July 2006, there was a peak in the number of species, without any relationship to the rainy season.

\section{DISCUSSION}

In this study, serum samples with titers greater than or equal to 1:80 were regarded as positive. This limit has also been used by other researchers ${ }^{31326}$ for the Bio-Manguinhos immunofluorescence kit, in relation to Leishmania (Leishmania) chagasi.

Using this limit of 1:80, the number of cross-reactions with other parasites is lower ${ }^{26}$. Although the serological cross-reactivity between Leishmania sp and Trypanosoma sp is well defined, little is known about the influence of other microorganisms that infect dogs, such as Babesia canis, Erlichia canis and Plasmodium sp. Thus, the specificity of the immunofluorescence test is influenced by infections caused by different parasite species ${ }^{21}$.

In the state of Mato Grosso do Sul, the presence of Lutzomyia longipalpis was reported in the municipalities of Anastácio and Aquidauana and in the state capital, Campo Grande, where VL is transmitted by both Lutzomyia longipalpis and Lutzomyia cruzi $^{18}$. In Bonito, the frequency of Lutzomyia longipapis was $90.4 \%$, especially indoors and in areas surrounding homes, all year round. This species is thus believed to be the vector for $\mathrm{VL}$ in that region.

The presence of Bicromomyia flaviscutelatta, i.e. the main vector for Leishmania (Leishmania) amazonensis, indoors and in areas surrounding homes, is highly significant. This demonstrates gradual adaptation of this species to the human environment, in contrast with its previous restriction to wooded areas, as suggested by Oliveira et al ${ }^{18}$ and Nunes et $\mathrm{al}^{17}$ in studies conducted in Campo Grande, Mato Grosso do Sul, and in a studied carried out in Mato Grosso ${ }^{27}$. In Mato Grosso do Sul, Leishmania amazonensis has been reported to affect dogs, cats and humans ${ }^{422} 28$.

Nyssomyia whitmani, i.e. the vector for Leishmania (Viannia) braziliensis, was the fifth most abundant species. It was present both indoors and in areas surrounding homes, which shows that it has become adapted to human-modified environments, as seen in other Brazilian regions ${ }^{1}$ and in other studies in Mato Grosso do Sul ${ }^{171927}$.

The increasing environmental changes are bringing ACL and $V L$ vectors closer to humans ${ }^{41719}$. Capture of these insects in the Bonito region, in addition to findings of dogs that are seropositive for leishmaniasis, shows that these parasitic diseases are still being introduced into urban areas, thereby giving rise to new foci of these diseases. The results from the present study point towards a need for epidemiological surveillance to follow up the human occupation of the environment that is taking place in the Bonito region, especially because of its importance as a tourist center.

There also needs to be special training for tourist guides and for healthcare and educational workers, in order to make the community aware of the importance of environmental preservation and of the ways to avoid proliferation of phlebotomines, with the aim of decreasing leishmaniasis transmission in this region.

\section{REFERENCES}

1. Azevedo ACR, Villelle ML, Sousa NA, Andrade-Coelho CA, Barbosa AF Firmmino ALS, Rangel EF. The sandfly fauna (Diptera, Psychodidae, Phlebotominae) of a focus of cutaneous leishmaniasis in Ilhéus, State of Bahia, Brazil. Memória do Instituto Oswaldo Cruz 1: 75-79, 1996.

2. Cortada VM, Dorval MEMC, Souza LMAA, Oshiro ET, Meneses CRV, Abreu-Silva AL, Cupollillo E, Souza CSF, Cardoso FO, Zaverucha do Valle T, Brazil RP, Calabrese KS, Gonçalves da Costa SC. Canine visceral leishmaniasis in Anastácio, Mato Grosso do Sul State, Brazil. Veterinary Research Communication 5: 365-374, 2004.

3. Dorval MEMC, Oshiro ET, Cupollillo E, Castro ACC, Alves TP. Ocorrência de leishmaniose tegumentar americana no Estado do Mato Grosso do Sul associada à infecção por Leishmania (Leishmania) amazonensis. Revista da Sociedade Brasileira de Medicina Tropical 1: 43-46, 2006.

4. Galati EAB. Morfologia e taxonomia: classificação de Phlebotominae. In: Rangel $\mathrm{E}$, Lainson $\mathrm{R}$ (orgs) Flebotomíneos do Brasil, Fundação Instituto Oswaldo Cruz, Rio de Janeiro, p. 23-51, 2003.

5. Galati EAB, Nunes VLB, Cristaldo G. Aspectos do comportamento da fauna flebotomínea (Diptera: Psychodidae) em foco de leishmaniose visceral e tegumentar na Serra da Bodoquena e área adjacente, Estado de Mato Grosso do Sul, Brasil. Revista da Sociedade Brasileira de Medicina Tropical 2: 235-261, 2003

6. Gontijo CMF, Melo MN. Leishmaniose visceral no Brasil, quadro atual, desafios e perspectivas. Revista Brasileira de Entomologia 3:338-349, 2004

7. Hayek LAC, Buzas MA. Surveying Natural Populations. Columbia University Press, New York, 1997.

8. Haddow AJS. Studies on the biting habits and medical importance of East African mosquitoes in the genus Aedes. I - Subgenero Aedimorphus, Banksinella and Nunnius. Bulletin of Entomology Research 50:759-79, 1960

9. Instituto Brasileiro de Geografia e Estatística. Cidades, Bonito, 2006. Disponível em: <http:// www.ibge.gov.br-cidades2007>. Acesso em: 23 maio 2007.

10. Jesus RCS, Correa ZCJ, Everdosa DR, Martins AP, Eliseu LS, Campos MB, Jennings, YLL, Ishikawa EAY, Souza AA, Silveira FT. Comparação das técnicas de RIFI (Ag. IEC X Ag. Bio-Manguinhos) e ELISA no sorodiagnóstico da leishmaniose visceral canina (LVC), Estado do Pará, Brasil. Revista da Sociedade Brasileira de Medicina Tropical 36 (supl I): 323, 2003.

11. Lonardoni MVC, Bernal FHZ, Silveira TVG, Antunes V, Teodoro U, Jorge FA Zanzarini PD. Comparação entre imunofluorescência indireta e aglutinação direta para o diagnóstico sorológico da Leishmaniose tegumentar americana em cães errantes. Arquivo Brasileiro de Medicina Veterinária e Zootecnia 6: 1001-1008, 2006

12. Ministério da Saúde. Sistema de notificação de agravos (SINAN). Campo Grande Leishmaniose visceral, 2007. Disponível em: <http://dtr2004.saude.gov.br/ sinanweb/index.php?name=Tnet $>$. Acesso em: 4 abr. 2007.

13. Moreira MAB, Livizzoto MCR, Nunes CM, Silva TCC, Laurentti MD, Corbett CEP. Aplicação da técnica de imunofluorescência direta para o diagnóstico da leishmaniose visceral canina em aspirado de linfonodo. Brazilian Journal of Veterinary Research and Animal Science 2: 103-106, 2002.

14. Natal D, Marucci D, Reis IM, Galati EAB. Modificações da armadilha CDC com testes para coletas de flebotomíneos (Diptera). Revista Brasileira de Entomologia 35:697-700, 1991 .

15. Neves DP. Parasitologia humana, $10^{\text {th }}$ edition. Editora Atheneu, São Paulo, 2003.

16. Nunes VLB, Dorval MEMC, Oshiro ET, Noguchi RC, Arão LB, Hans Filho G. Estudo epidemiológico sobre leishmaniose tegumentar (LT) no município de Corguinho, Mato Grosso do Sul: estudos na população humana. Revista da Sociedade Brasileira de Medicina Tropical 28:185-193, 1995.

17. Nunes VLB, Galati EAB, Cardozo C, Rocca MEG, Andrade ARO, Santos MFC Aquino EB, Rosa D. Estudo de flbotomíneos (Díptera, Psychodidade) em área 
urbana do município de Bonito, Mato Grosso do Sul, Brasil. Revista Brasileira de Entomologia 52:446-451, 2008.

18. Oliveira AG, Andrade-Filho JD, Falcão AL, Brazil RP. Estudo da fauna flebotomínea (Díptera, Psychodidade, Phlebotominae) na zona urbana da cidade de Campo Grande, Mato Grosso do Sul, Brasil 1999-2000. Cadernos de Saúde Pública 4: 933-944, 2003.

19. Oliveira AG, Galati EAB, Oliveira O, Oliveira GRO, Espindola IAC, Dorval MEMC, Brazil RP. Abundance of Lutzomyia longipalpis (Diptera: Psychodidae: Phlebotominae) and urban transmission of visceral leishmaniasis in Campo Grande, state of Mato Grosso do Sul, Brazil. Memórias do Instituto Oswaldo Cruz 8: 869-874, 2006

20. Rey L. Parasitologia. $3^{\text {th }}$ edition. Editora Guanabara Koogan, Rio de Janeiro, 2001.

21. Roberta DR, His BP. An index of species abundance for use with mosquito surveillance data. Environmental Entomology 8:1-13, 1979.

22. Saraiva L, Lopes JS, Oliveira GBM, Batista FA, Falcão AL, Andrade Filho JD. Estudo dos flebotomíneos (Díptera: Psychodidae) em área de leishmaniose tegumentar americana nos municípios de Alto Caparaó e Caparaó, Estado de Minas Gerais. Revista da Sociedade Brasileira de Medicina Tropical 1:56-63, 2006.

23. Savani EMS. Aspectos da transmissão de leishmanioses no Assentamento Guaicurus, Planalto da Bodoquena, Estado de Mato Grosso do Sul, Brasil,
2002-03. Infecção natural em animais domésticos e vetores. Tese de Doutorado, Faculdade de Saúde Pública da Universidade de São Paulo, SP, 2004.

24. Secretaria de Estado de Saúde de Mato Grosso do Sul. Leishmaniose tegumentar americana, 2007. Disponível em: <http://www.saude.ms.gov.br/index. php?templat=lis\&site=116comp $>$. Acesso em: 19 maio 2007 .

25. Sherlock IA. A Importância dos Flebotomíneos. In: Rangel EF, Lainson R (orgs) Flebotomíneos do Brasil. Fundação Instituto Oswaldo Cruz, Rio de Janeiro. p.15-21, 2003.

26. Silva RM. Estudo comparativo entre os métodos de Elisa e Imunofluorescência indireta na analise de amostras de sangue de cães provenientes de municípios endêmicos e enzoóticos para LVA. Tese de Doutorado, Faculdade de Saúde Pública da Universidade de São Paulo, SP, 2005.

27. Ribeiro AL, Missawa NA, Zeilhofer P. Distribution of plhebotomine sandflies (Diptera: Psychodidae) of medical importance in Mato Grosso State, Brazil. Revista do Instituto de Medicina Tropical de São Paulo 49:317-321, 2007.

28. Souza AI, Barros SEM, Ishikawa E, Ilha IMN, Marin GRB, Nunes VLB. Feline leishmaniasis due to Leishmania (Leishmania) amazonensis in Mato Grosso do Sul State, Brazil. Veterinary Parasitology 1-2:41-45, 2005. 